\title{
INTERNATIONAL EXPERIENCES WITH DIFFERENT MONETARY POLICY REGIMES
}

\author{
Frederic S. Mishkin \\ Working Paper 6965 \\ http://www.nber.org/papers/w6965
NATIONAL BUREAU OF ECONOMIC RESEARCH
1050 Massachusetts Avenue
Cambridge, MA 02138
February 1999

Prepared for Sveriges Riksbank-IIES Conference on Monetary Policy Rules, Stockholm, Sweden, June 1213, 1998. I thank for their helpful comments my discussant, Charles Goodhart, as well as my coauthors for our book, Inflation Targeting: Lessons from the International Experience (Princeton University Press, 1999) on which a substantial part of the discussion in this paper is based, Ben Bernanke, Thomas Laubach, and Adam Posen. Any views expressed in this paper are those of the author only and not those of Columbia University or the National Bureau of Economic Research.

(C) 1999 by Frederic S. Mishkin. All rights reserved. Short sections of text, not to exceed two paragraphs, may be quoted without explicit permission provided that full credit, including ${ }^{\circledR}$ notice, is given to the source. 
International Experiences with

Different Monetary Policy Regimes

Frederic S. Mishkin

NBER Working Paper No. 6965

February 1999

JEL No. E5

\begin{abstract}
This paper examines the international experiences with four basic types of monetary policy regimes: 1) exchange-rate targeting, 2) monetary targeting, 3) inflation targeting, and 4) monetary policy with an implicit but not an explicit nominal anchor. The basic theme that emerges from this analysis is that transparency and accountability are crucial to constraining discretionary monetary policy so that it produces desirable long-run outcomes. Because the devil is in the details in achieving transparency and accountability, what strategy will work best in a country depends on its political, cultural and economic institutions and its past history.
\end{abstract}

Frederic S. Mishkin

Uris Hall 619

Columbia University

New York, New York 10027

and NBER

fsm3@columbia.edu 
In recent years a growing consensus has emerged for price stability as the overriding, long-run goal of monetary policy. However, despite this consensus, the following question still remains: how should monetary policy be conducted to achieve the price stability goal? To shed light on this question, this paper examines the experience with different monetary policy regimes currently in use in a number of countries.

A central feature of all of the monetary regimes discussed here is the use of a nominal anchor in some form, so first we will examine what role a nominal anchor plays in promoting price stability. Then we will examine four basic types of monetary policy regimes: 1) exchange-rate targeting, 2) monetary targeting, 3) inflation targeting, and 4) monetary policy with an implicit but not an explicit nominal anchor. The paper then concludes with an overall assessment of the different monetary regimes and draws some policy conclusions. The basic theme that comes out of this analysis is that the success of different monetary regimes depends on their ability to constrain discretionary policymaking so that long-run price stability is more likely to result.

\section{I. The Role of a Nominal Anchor}

A nominal anchor is a constraint on the value of domestic money, and in some form it is a necessary element in successful monetary policy regimes. Why is a nominal anchor needed? First, from a purely technical viewpoint, a nominal anchor provides conditions that make the price level uniquely determined, which is obviously necessary for price stability. Indeed, it helps promote price stability because it helps tie down inflation expectations directly through its constraint on the value of domestic money.

However, a nominal anchor can be thought of more broadly as a constraint on discretionary policy that helps weaken the time-inconsistency problem described by Kydland and Prescott (1977), Calvo (1978) and Barro and Gordon (1983) so that in the long run, price stability is a more likely to be achieved. The time-inconsistency problem arises because there are incentives for a policymaker to pursue short-run objectives even though the result is poor long-run outcomes which result from 
forward-looking behavior on the part of economic agents. Expansionary monetary policy will produce higher growth and employment in the short-run, and so policymakers will be tempted to pursue this policy even though it will not produce higher growth and employment in the long-run because economic agents adjust their wage and price expectations upward to reflect the expansionary policy. Unfortunately, however, the expansionary monetary policy will lead to higher inflation in the long-run, with its negative consequences for the economy.

McCallum (1995) points out that the time-inconsistency problem by itself does not imply that a central bank will pursue expansionary monetary policy which leads to inflation. Simply by recognizing the problem that forward-looking expectations in the wage- and price-setting process creates for a strategy of pursuing expansionary monetary policy, central banks can decide not to play that game. However, even if the central bank recognizes the problem, there still will be pressures on the central bank to pursue overly expansionary monetary policy by the politicians. Thus overly expansionary monetary policy and inflation may result, so that the time-inconsistency problem remains: the time-inconsistency problem is just shifted back one step. Thus even if the source of time inconsistency is not within central banks, a nominal anchor may be needed to limit political pressures to pursue overly expansionary, time-inconsistent, monetary policies.

\section{II. Exchange-Rate Targeting}

Targeting the exchange rate is a monetary policy regime with a long history. It can take the form of fixing the value of the domestic currency to a commodity such as gold, the key feature of the gold standard. More recently, fixed exchange-rate regimes have involved fixing the value of the domestic currency to that of a large, low-inflation country. As another alternative, instead of fixing the value of the currency to that of the low-inflation anchor country, which implies that the inflation rate will eventually gravitate to that of the anchor country, some countries adopt a crawling target or peg in which its currency is allowed to depreciate at a steady rate so that its inflation can be higher than that of the anchor country. 
Exchange-rate targeting has several advantages. First, the nominal anchor of an exchangerate target fixes the inflation rate for internationally traded goods, and thus directly contributes to keeping inflation under control. Second, if the exchange-rate target is credible, it anchors inflation expectations to the inflation rate in the anchor country to whose currency it is pegged. Third, an exchange-rate target provides an automatic rule for the conduct of monetary policy that avoids the time-inconsistency problem. It forces a tightening of monetary policy when there is a tendency for the domestic currency to depreciate or a loosening of policy when there is a tendency for the domestic currency to appreciate. Monetary policy no longer has the discretion that can result in the pursuit of expansionary policy to obtain employment gains which lead to time-inconsistency. Fourth, an exchange-rate target has the advantage of simplicity and clarity, which make it easily understood by the public. A "sound currency" is an easy-to-understand rallying cry for monetary policy. This has been important in France, for example, where an appeal to the "franc fort" is often used to justify tight monetary policy.

Given its advantages, it is not surprising that exchange-rate targeting has been used successfully to control inflation in industrialized countries. Both France and the United Kingdom, for example, successfully used exchange-rate targeting to lower inflation by tying the value of their currencies to the German mark. In 1987, when France first pegged their exchange rate to the mark, its inflation rate was 3\%, two percentage points above the German inflation rate. By 1992 its inflation rate had fallen to $2 \%$, a level that can be argued is consistent with price stability, and was even below that in Germany. By 1996, the French and German inflation rates had converged, to a number slightly below $2 \%$. Similarly, after pegging to the German mark in 1990, the United Kingdom was able to lower its inflation rate from $10 \%$ to $3 \%$ by 1992 , when it was forced to abandon the Exchange Rate Mechanism (ERM).

Exchange-rate targeting has also been an effective means of reducing inflation quickly in emerging market countries. An important recent example has been Argentina, which in 1990 established a currency board arrangement, requiring the central bank to exchange U.S. dollars for new pesos at a fixed exchange rate of 1 to 1 . The currency board is an especially strong and transparent commitment to an exchange-rate target because it requires that the note-issuing authority, whether the central bank or the government, stands ready to exchange the domestic currency for foreign 
currency at the specified fixed exchange rate whenever the public requests it. In order to credibly meet these requests, a currency board typically has more than $100 \%$ foreign reserves backing the domestic currency and allows the monetary authorities absolutely no discretion. The early years of Argentina's currency board looked stunningly successful. Inflation which had been running at over a one-thousand percent annual rate in 1989 and 1990 fell to under 5\% by the end of 1994, and economic growth was rapid, averaging almost 8\% at an annual rate from 1991 to 1994.

Despite the inherent advantages of exchange-rate targeting, it is not without its serious problems, as the international experience demonstrates. There are several serious criticisms of exchange-rate targeting. First is that an exchange-rate target results in the loss of independent monetary policy. ${ }^{1}$ With open capital markets, an exchange-rate target causes domestic interest rates to be closely linked to those of the anchor country. The targeting country thus loses the ability to use monetary policy to respond to domestic shocks that are independent of those hitting the anchor country. Furthermore, an exchange-rate target means that shocks to the anchor country are directly transmitted to the targeting country because changes in interest rates in the anchor country lead to a corresponding change in interest rates in the targeting country.

A striking example of these problems occurred when Germany reunified in 1990. Concerns about inflationary pressures arising from reunification and the massive fiscal expansion required to rebuild East Germany led to rises in German long-term interest rates until February 1991 and to rises in short-term rates until December 1991. This shock to the anchor country in the Exchange Rate Mechanism (ERM) was transmitted directly to the other countries in the ERM whose currencies were pegged to the mark because their interest rates now rose in tandem with those in Germany. As pointed out in Clarida, Gali and Gertler (1997), monetary policy in countries such as France and the United Kingdom was far tighter than would have been the case if monetary policy in these countries was focused on domestic considerations. The result was that continuing adherence to the exchangerate target produced a significant slowing of economic growth and rising unemployment, which is exactly what France experienced when it remained in the ERM and adhered to the exchange-rate peg.

A second problem with exchange-rate targets has been pointed out forcefully in Obstfeld and

${ }^{1}$ See Obstfeld and Rogoff (1995) for additional discussion of this criticism. 
Rogoff (1995): exchange-rate targets leave countries open to speculative attacks on their currencies. Indeed, one aftermath of German reunification was the foreign exchange crisis of September 1992. As we have seen, the tight monetary policy in Germany resulting from German reunification meant that the countries in the ERM were subjected to a negative demand shock that led to a decline in economic growth and a rise in unemployment. It was certainly feasible for the governments of these countries to keep their exchange rates fixed relative to the mark in these circumstances, but speculators began to question whether these countries' commitment to the exchange rate peg would weaken because these countries would not tolerate the rise in unemployment that would result from keeping interest rates sufficiently high to fend off speculative attacks on their currencies.

At this stage, speculators were in effect presented with a one-way bet: the exchange rates for currencies such as the French franc, the Spanish peseta, the Swedish krona, the Italian lira and the British pound could only go in one direction, depreciate against the mark. Selling these currencies thus presented speculators with an attractive profit opportunity with potentially high expected returns and yet little risk. The result was that in September 1992, a speculative attack on the French franc, the Spanish peseta, the Swedish krona, the Italian lira and the British pound began in earnest. Only in France was the commitment to the fixed exchange rate strong enough, so that France did not devalue. The governments in Britain, Spain, Italy and Sweden were unwilling to defend their currencies at all costs and so allowed their currencies to fall in value.

The attempted defense of these currencies did not come cheaply. By the time the crisis was over, the British, French, Italian, Spanish and Swedish central banks had intervened to the tune of an estimated $\$ 100$ billion, and the Bundesbank alone had laid out an estimated $\$ 50$ billion for foreign exchange intervention. It is further estimated that these central banks lost $\$ 4$ to $\$ 6$ billion as a result of their exchange-rate intervention in the crisis, an amount that was in effect paid by taxpayers in these countries.

The different response of France and the United Kingdom after the September 1992 exchange rate crisis illustrates the potential cost of an exchange-rate target. France, which continued to peg to the mark and thereby was unable to use monetary policy to respond to domestic conditions, found that economic growth remained slow after 1992 and unemployment increased. The United Kingdom, on the other hand, which dropped out of the ERM exchange-rate peg and adopted inflation targeting 
(discussed later), had much better economic performance: economic growth was higher, the unemployment rate fell, and yet inflation performance was not much worse than France's.

The aftermath of German reunification and the September 1992 exchange rate crisis dramatically illustrate two points: 1) an exchange-rate target does not guarantee that the commitment to the exchange-rate based, monetary policy rule is sufficiently strong to maintain the target, and 2) the cost to economic growth from an exchange-rate regime with its loss of independent monetary policy can be high.

For emerging market countries, it is far less clear that these countries lose much by giving up an independent monetary policy when they target exchange rates. Because many emerging market countries have not developed the political or monetary institutions that result in the ability to use discretionary monetary policy successfully, they may have little to gain from an independent monetary policy, but a lot to lose. Thus, they would be better off by, in effect, adopting the monetary policy of a country like the United States through targeting exchange rates than in pursuing their own independent policy. Indeed, this is one of the reasons that so many emerging market countries have adopted exchange-rate targeting. ${ }^{2}$

Nonetheless, as is emphasized in Mishkin (1997, 1998), there is an additional disadvantage from an exchange-rate target in emerging market countries that suggests that for them this monetary policy regime is highly dangerous. Exchange-rate targeting in emerging market countries is likely to promote financial fragility and possibly a full-fledged financial crisis that can be highly destructive to the economy.

To see why exchange-rate targets in an emerging market country make a financial crisis more likely, we must first understand what a financial crisis is and why it is so damaging to the economy. In recent years, an asymmetric information theory of financial crises has been developed which provides a definition of a financial crisis [Bernanke (1983), Calomiris and Gorton (1991), and Mishkin (1991, 1994, 1996).] A financial crisis is a nonlinear disruption to financial markets in which

\footnotetext{
${ }^{2}$ This also explains why of all the countries entering the European Monetary Union, Italy has the most public support for EMU. In the past, monetary policy in Italy has not been too successful and therefore adopting the monetary policy of the European Central Bank, which is patterned after the Bundesbank, seems particularly attractive.
} 
asymmetric information problems (adverse selection and moral hazard) become much worse, so that financial markets are unable to efficiently channel funds to economic agents who have the most productive investment opportunities. A financial crisis thus prevents the efficient functioning of financial markets, which therefore leads to a sharp contraction in economic activity.

Because of uncertainty about the future value of the domestic currency, many nonfinancial firms, banks and governments in emerging market countries find it much easier to issue debt if the debt is denominated in foreign currencies. This tendency can be further encouraged by an exchangerate targeting regime which may encourage domestic firms and financial institutions to issue foreign denominated debt. The substantial issuance of foreign denominated debt was a prominent feature of the institutional structure in the Chilean financial markets before the financial crisis in 1982, in Mexico before its financial crisis in 1994 and in East Asian countries before their recent crisis.

With an exchange-rate target regime, depreciation of the currency when it occurs is a highly nonlinear event because it involves a devaluation. In most developed countries a devaluation has little direct effect on the balance sheets of households, firms and banks because their debts are denominated in domestic currency. ${ }^{3}$ This is not true, however, in emerging market countries with their very different institutional structure. In these countries, but not in developed countries, a foreign exchange crisis can trigger a full-scale financial crisis in which financial markets are no longer able to move funds to those with productive investment opportunities, thereby causing a severe economic contraction.

With debt contracts denominated in foreign currency as in emerging market countries, when there is a devaluation of the domestic currency, the debt burden of domestic firms increases. On the other hand, since assets are typically denominated in domestic currency, there is no simultaneous increase in the value of firms' assets. The result is a that a devaluation leads to a substantial deterioration in firms' balance sheets and a decline in net worth, which, in turn, means that effective collateral has shrunk, thereby providing less protection to lenders. Furthermore, the decline in net

\footnotetext{
${ }^{3}$ Indeed, a devaluation in developed countries can actually stimulate economic activity because it makes the country's goods more competitive internationally, thereby increasing its net exports and hence aggregate demand. Indeed, this was exactly the experience of the United Kingdom after the September 1992 foreignexchange crisis when it was forced to devalue its currency. Its economic performance after the devaluation was substantially better than that of countries which remained in the ERM after 1992.
} 
worth increases moral hazard incentives for firms to take on greater risk because they have less to lose if the loans go sour. Because lenders are now subject to much higher risks of losses, there is now a decline in lending and hence a decline in investment and economic activity. The damage to balance sheets from devaluation in the aftermath of the foreign exchange crisis was a major source of the contraction of the economies of Chile in 1982, Mexico in 1994 and 1995 and East Asia in 1997-98.

In addition, the depreciation of the domestic currency can lead to deterioration in the balance sheets of the banking sector. In emerging market countries, banks typically have many short-term liabilities denominated in foreign currency which increase sharply in value when a depreciation occurs. On the other hand, the problems of firms and households mean that they are unable to pay off their debts, also resulting in loan losses on the assets side of the banks' balance sheets. Once there is a deterioration in bank balance sheets, with the substantial loss of bank capital, banks have two choices: either 1) they can cut back on their lending in order to shrink their asset base and thereby restore their capital ratios, or 2) they can try to raise new capital. However, when banks experience a deterioration in their balance sheets, it is very hard for them to raise new capital at a reasonable cost. Thus, the typical response of banks with weakened balance sheets is a contraction in their lending, which slows economic activity. In the extreme case in which the deterioration of bank balance sheets leads to a banking crisis which forces many banks to close their door, thereby directly limiting the ability of the banking sector to make loans, the affect on the economy is even more severe.

An additional danger from using an exchange-rate target in emerging market countries is that although the exchange-rate target is initially successful in bringing inflation down -- for example, Mexican inflation fell from over a 100\% annual rate before it adopted exchange-rate targets in 1988 to inflation rates in the single digits by 1994 -- a successful speculative attack can lead to a resurgence of inflation. Because many emerging market countries have previously experienced both high and variable inflation, their central banks are unlikely to have deep-rooted credibility as inflation fighters. Thus, a sharp depreciation of the currency after a speculative attack that leads to immediate upward pressure on prices can lead to a dramatic rise in both actual and expected inflation. Indeed Mexican inflation surged to 50\% in 1995 after the foreign exchange crisis in 1994 and a similar phenomenon has been occurring in Indonesia.

A rise in expected inflation after a successful speculative attack against the currency of an 
emerging market country is another factor exacerbating the financial crisis because it leads to a sharp rise in interest rates as occurred in Mexico and the East Asian crisis countries. The interaction of the short duration of debt contracts and the rise in interest rates leads to huge increases in interest payments by firms, thereby weakening firms' cash flow position and further weakening their balance sheets. Then, as we have seen, both lending and economic activity are likely to undergo a sharp decline.

Another potential danger from an exchange-rate target is that by providing a more stable value of the currency, it might lower perceived risk for foreign investors and thus encourage capital inflows. Although these capital inflows might be channeled into productive investments and thus stimulate growth, they might promote excessive lending, manifested by a lending boom, because domestic financial intermediaries such as banks play a key role in intermediating these capital inflows [Calvo, Leiderman and Reinhart (1994)]. Indeed, Folkerts-Landau, et. al (1995) found that emerging market countries in the Asian-Pacific region with the large net private capital inflows also experienced large increases in their banking sectors. Furthermore, if the bank supervisory process is weak, as it often is in emerging market countries, so that the government safety net for banking institutions creates incentives for them to take on risk, the likelihood that a capital inflow will produce a lending boom is that much greater. With inadequate bank supervision, the likely outcome of a lending boom is substantial loan losses and a deterioration of bank balance sheets. ${ }^{4}$

The deterioration in bank balance sheets can damage the economy in two ways. First, the deterioration in the balance sheets of banking firms leads them to restrict their lending in order to improve their capital ratios or can even lead to a full-scale banking crisis which forces many banks into insolvency, thereby directly removing the ability of the banking sector to make loans. Second, the deterioration in bank balance sheets can promote a foreign exchange crisis because it becomes very difficult for the central bank to defend its currency against a speculative attack. Any rise in interest rates to keep the domestic currency from depreciating has the additional effect of weakening

${ }^{4}$ Gavin and Hausman (1996) and Kaminsky and Reinhart (1996) do find that lending booms are a predictor of banking crises, yet it is less clear that capital inflows will necessarily produce a lending boom which causes a deterioration in bank balance sheets. Kaminsky and Reinhart (1996), for example, find that financial liberalization, rather than balance of payments developments inflows, appears to be a more important predictor of banking crises. 
the banking system further because the rise in interest rates hurts banks' balance sheets. This negative effect of a rise in interest rates on banks' balance sheets occurs because of their maturity mismatch and their exposure to increased credit risk when the economy deteriorates. Thus, when a speculative attack on the currency occurs in an emerging market country, if the central bank raises interest rates sufficiently to defend the currency, the banking system may collapse. Once investors recognize that a country's weak banking system makes it less likely that the central bank will take the steps to successfully defend the domestic currency, they have even greater incentives to attack the currency because expected profits from selling the currency have now risen. The outcome is a successful attack on the currency, and the resulting foreign exchange crisis causes a collapse of the economy for the reasons already discussed.

The recent events in Southeast Asia and Mexico, in which the weakness of the banking sector and speculative attack on the currency tipped their economies into full-scale financial crises, illustrate how dangerous exchange-rate targeting can be for emerging market countries. Indeed, the fact that an exchange-rate target in these countries leaves them more prone to financial fragility and financial crises, with potentially catastrophic costs to their economies, suggests that exchange-rate targeting in emerging market countries is highly problematic.

An additional disadvantage of an exchange-rate target is that it can weaken the accountability of policymakers, particularly in emerging market countries, because it eliminates an important signal that can help keep monetary policy from becoming too expansionary. In industrialized countries, and particularly in the United States, the bond market provides an important signal about the stance of monetary policy. Overly expansionary monetary policy or strong political pressure to engage in overly expansionary monetary policy produces an inflation scare of the type described by Goodfriend (1993) in which long-term bond prices tank and long-term rates spike upwards. In many countries, particularly emerging market countries, the long-term bond market is essentially nonexistent. In these countries, the daily fluctuations of the exchange rate can, like the bond market in the United States, provide an early warning signal that monetary policy is overly expansionary. Thus, like the bond market, the foreign exchange market can constrain policy from being too expansionary. Just as the fear of a visible inflation scare constrains central bankers from pursuing overly expansionary monetary policy and also constrains politicians from putting pressure on the central bank to engage in overly 
expansionary monetary policy, fear of exchange rate depreciations can make overly expansionary monetary policy less likely.

An exchange-rate target has the important disadvantage that it removes the signal that the foreign exchange market provides about the stance of monetary policy on a daily basis. Under an exchange-rate-target regime, central banks often pursue overly expansionary policies that are not discovered until too late, when a successful speculative attack has gotten underway. The problem of lack of accountability of the central bank under an exchange-rate-target regime is particularly acute in emerging market countries where the balance sheets of the central banks are not as transparent as in developed countries, thus making it harder to ascertain the central bank's policy actions. Although, an exchange-rate peg appears to provide rules for central bank behavior that eliminates the timeinconsistency problem, it can actually make the time-inconsistency problem more severe because it may actually make central bank actions less transparent and less accountable.

One solution to this problem is to strengthen the transparency and commitment to the exchange-rate target by adopting a currency board as has been done in Argentina. Although the stronger commitment to a fixed exchange rate may mean that a currency board is better able to stave off a speculative attack against the domestic currency than an exchange-rate peg, it is not without its problems. In the aftermath of the Mexican peso crisis, concern about the health of the Argentine economy resulted in the public pulling their money out of the banks (deposits fell by 18\%) and exchanging their pesos for dollars, thus causing a contraction of the Argentine money supply. The result was a sharp contraction in Argentine economic activity with real GDP dropping over 5\% in 1995 and the unemployment rate jumping to above 15\%. Only in 1996, with financial assistance from international agencies such as the IMF, the World Bank and the Inter-American Development Bank, which lent Argentina over $\$ 5$ billion to help shore up its banking system, did the economy begin to recover, and in recent years Argentina's economy has been performing quite well. Because the central bank of Argentina had no control over monetary policy under the currency board system, it was relatively helpless to counteract the contractionary monetary policy stemming from the public's behavior. Furthermore, because the currency board does not allow the central bank to create money and lend to the banks, it limits the capability of the central bank to act as a lender of last resort, and 
other means must be used to cope with potential banking crises. ${ }^{5}$

Although a currency board is highly problematic, it may be the only way to break a country's inflationary psychology and alter the political process so that it no longer leads to continuing bouts of high inflation. This indeed was the rationale for putting a currency board into place in Argentina, where past experience had suggested that stabilization programs with weaker commitment mechanisms would not work. Thus, implementing a currency board might be a necessary step to control inflation in countries that require a very strong disciplinary device.

\section{III. Monetary Targeting}

In many countries, exchange-rate targeting is not an option because the country (or bloc of countries) is too large or has no obvious country whose currency can serve as the nominal anchor. Exchange-rate targeting is therefore clearly not an option for the United States, Japan or the European Monetary Union. Thus these countries, by default, must look to other monetary policy regimes, one of which is monetary targeting.

A major advantage of monetary targeting over exchange-rate targeting is that it enables a central bank to adjust its monetary policy to cope with domestic considerations. It enables the central bank to choose goals for inflation that may differ from those of other countries and allows some response to output fluctuations. Also, like an exchange-rate target, information on whether the central bank is achieving its target is known almost immediately -- announced figures for monetary aggregates are typically reported periodically with very short time-lags, within a couple of weeks. Thus, monetary targets can send almost immediate signals to both the public and markets about the stance of monetary policy and the intentions of the policymakers to keep inflation in check. These signals then can help fix inflation expectations and produce less inflation. Monetary targets also have the advantage of being able to promote almost immediate accountability for monetary policy to keep inflation low and so help constrain the monetary policymaker from falling into the time-inconsistency

${ }^{5}$ See Mishkin (1998a) for a further discussion of what steps need to be taken to make the success of a currency board more likely. 
trap.

All of the above advantages of monetary aggregate targeting depend on two big ifs. The biggest if is that there must be a strong and reliable relationship between the goal variable (inflation or nominal income) and the targeted aggregate. If there is velocity instability, so that the relationship between the monetary aggregate and the goal variable is weak, then monetary aggregate targeting will not work. The weak relationship implies that hitting the target will not produce the desired outcome on the goal variable and thus the monetary aggregate will no longer provide an adequate signal about the stance of monetary policy. Thus, monetary targeting will not help fix inflation expectations and be a good guide for assessing the accountability of the central bank. The breakdown of the relationship between monetary aggregates and goal variables such as inflation and nominal income certainly seems to have occurred in the United States (Stock and Watson, 1989, Friedman, 1995, Friedman and Kuttner, 1993 and 1996, and Estrella and Mishkin, 1997) and may also be a problem even for countries that have continued to pursue monetary targeting.

The second if is that the targeted monetary aggregate must be well controlled by the central bank. If not, the monetary aggregate may not provide as clear signals about the intentions of the policymakers and thereby make it harder to hold them accountable. Although narrow monetary aggregates are easily controlled by the central bank, it is far from clear that this is the case for broader monetary aggregates like M2 or M3 (see B. Friedman [1995]).

These two problems with monetary targeting suggest one reason why even the most avid monetary targeters do not rigidly hold to their target ranges, but rather allow undershoots and overshoots for extended periods of time. Moreover, an unreliable relationship between monetary aggregates and goal variables calls into question the ability of monetary targeting to serve as a communications device that both increases the transparency of monetary policy and makes the central bank accountable to the public.

In the 1970s, monetary targeting was adopted by several countries but its form was quite different from Milton Friedman's suggestion for a constant-money-growth-rate rule in which the chosen monetary aggregate is targeted to grow at a constant rate. Indeed, as emphasized by Bernanke and Mishkin (1992), in all these countries the central banks never adhered to strict, ironclad rules for monetary growth and in some of these countries monetary targeting was not pursued terribly 
seriously. For example, the United States, Canada and the especially the United Kingdom, engaged in substantial gameplaying in which they targeted multiple aggregates, allowed base drift, did not announce targets on a regular schedule, used artificial means to bring down the growth of a targeted aggregate (the corset in the U.K.), often overshot their targets without reversing the overshoot later and often obscured why deviations from the monetary targets occurred.

Monetary targeting in the United States, Canada and the United Kingdom did not prove to be successful in controlling inflation and there are two interpretations for why this was the case. One is that because monetary targeting was not pursued seriously, it never had a chance to be successful. Second is that growing instability of the relationship between monetary aggregates and goal variables such as inflation (or nominal income) meant that this strategy was doomed to failure and indeed was not pursued seriously because to do so would have been a mistake. By the early 1980s, it was becoming very clear that the relationship between monetary aggregates and inflation and nominal income had broken down and all three countries formally abandoned monetary targeting. Or as attributed to John Crow, but actually said by Gerald Bouey, both former governors of the Bank of Canada, "We didn't abandon monetary aggregates, they abandoned us."

The two countries which have officially engaged in monetary targeting for over twenty years starting at the end of 1974 have been Germany and Switzerland. The success of monetary policy in these two countries in controlling inflation is the reason that monetary targeting still has strong advocates and is under consideration as the official policy regime for the European Central Bank.

The key fact about monetary targeting regimes in Germany and Switzerland is that the targeting regimes are very far from a Friedman-type monetary targeting rule in which a monetary aggregate is kept on a constant-growth-rate path and is the primary focus of monetary policy. As Otmar Issing, currently the Chief Economist of the Bundesbank has noted (Issing 1996, p. 120), "One of the secrets of success of the German policy of money-growth targeting was that ... it often did not feel bound by monetarist orthodoxy as far as its more technical details were concerned." Monetary targeting in Germany and Switzerland should instead be seen primarily as a method of communicating the strategy of monetary policy that focuses on long-run considerations and the control of inflation.

As is emphasized in Neumann and von Hagen (1993), Bernanke and Mishkin (1992), Mishkin 
and Posen (1997) and our forthcoming book, Bernanke, Laubach, Mishkin and Posen (1999), the calculation of monetary target ranges is a very public exercise. First and foremost, a numerical inflation goal is prominently featured in the setting of target ranges. Then with estimates of potential output growth and velocity trends, a quantity-equation framework is used to back out the target growth rate for the monetary aggregate. Second, monetary targeting, far from being a rigid policy rule, has been quite flexible in practice. The target ranges for money growth are missed on the order of fifty percent of the time, often because the Bundesbank's and the Swiss National Bank's concern about other objectives, including output and exchange rates. ${ }^{6}$ Furthermore, the Bundesbank has demonstrated its flexibility by allowing its inflation goal to vary over time and to converge slowly to the long-run inflation goal quite gradually.

When the Bundesbank first set its monetary targets at the end of 1974, it announced a medium-term inflation goal of $4 \%$, well above what it considered to be an appropriate long-run goal for inflation. It clarified that this medium-term inflation goal differed from the long-run goal by labelling it the "unavoidable rate of price increase". Its gradualist approach to reducing inflation led to a period of nine years before the medium-term inflation goal was considered to be consistent with price stability. When this occurred at the end of 1984, the medium-term inflation goal was renamed the "normative rate of price increases" and was set at $2 \%$ and has continued at this level since then.

The Bundesbank has also responded to supply shocks by raising its medium-term inflation goal: specifically it raised the unavoidable rate of price increase from $3.5 \%$ to $4 \%$ in the aftermath of the second oil price shock in 1980.

Third, the monetary targeting regimes in both Germany and Switzerland have demonstrated a strong commitment to the communication of the strategy to the general public. The money-growth targets are continually used as a framework for explanation of the monetary policy strategy and both the Bundesbank and the Swiss National Bank expend tremendous effort, both in their publications and in frequent speeches by central bank officials, to communicate to the public what the central bank is trying to achieve. Indeed, given that both central banks frequently miss their money-growth targets by significant amounts, their monetary-targeting frameworks are best viewed as a mechanism for

${ }^{6}$ See Von Hagen (1995), Neumann (1996), Bernanke and Mihov (1996), Clarida and Gertler (1997), Mishkin and Posen (1997) and Bernanke, Laubach, Mishkin and Posen (1999). 
transparently communicating how monetary policy is being directed to achieve their inflation goals and as a means for increasing the accountability of the central bank.

Germany's monetary-targeting regime has been quite successful in producing low inflation and its success has been envied by many other countries, explaining why it was chosen as the anchor country for the Exchange Rate Mechanism. An important success story, discussed extensively in Mishkin and Posen (1997) and Bernanke, Laubach, Mishkin and Posen (1999), occurred in the aftermath of German reunification in 1990. Despite a temporary surge in inflation stemming from the terms of reunification, high wage demands and the fiscal expansion, the Bundesbank was able to keep these one-off effects from becoming embedded in the inflation process, and by 1995, inflation fell back down below the Bundesbank's normative inflation goal of $2 \%$.

One potentially serious criticism of German monetary targeting, however, is that, as demonstrated by Clarida and Gertler (1997), the Bundesbank has reacted asymmetrically to target misses, raising interest rates in response to overshooting of the money-growth target, but choosing not to lower interest rates in response to an undershooting. This suggests that the Bundesbank may not be sufficiently concerned about undershoots of its normative inflation goal. Arguably this might have caused the Bundesbank to be overly tight in its monetary policy stance in the mid 1990s when German inflation fell below the $2 \%$ normative goal, which not only led to an unnecessary increase in unemployment in Germany, but also in countries tied to the deutsche mark, such as France.

Monetary targeting in Switzerland has been more problematic in Switzerland than in Germany, suggesting the difficulties of targeting monetary aggregates in a small open economy which also underwent substantial changes in the institutional structure of its money markets. In the face of a $40 \%$ trade-weighted appreciation of the Swiss franc from the fall of 1977 to the fall of 1978, the Swiss National Bank decided that the country could not tolerate this high a level of the exchange rate. Thus, in the fall of 1978 the monetary targeting regime was abandoned temporarily, with a shift from a monetary target to an exchange-rate target until the spring of 1979, when monetary targeting was reintroduced although it was not announced. Furthermore, when the return to monetary targeting was formally announced in 1980, the Swiss National Bank deemed it necessary to switch the monetary aggregate targeted from M1 to the monetary base.

The period from 1989 to 1992 was also not a happy one for Swiss monetary targeting because 
as stated by the Chief Economist of the Swiss National Bank, Georg Rich, "the SNB [Swiss National Bank\} failed to maintain price stability after it successfully reduced inflation," (Rich 1997, p. 115, emphasis in original). The substantial overshoot of inflation from 1989 to 1992, reaching levels above 5\%, was due to two factors. The first is that the strength of the Swiss franc from 1985 to 1987 caused the Swiss National Bank to allow the monetary base to grow at a rate greater than the $2 \%$ target in 1987 and then raised the money-growth target to $3 \%$ for 1988. The second arose from the introduction of a new interbank payment system, the Swiss Interbank Clearing (SIC) and a wideranging revision of the commercial banks' liquidity requirements in 1988 . The result of the shocks to the exchange rate and the shift in the demand for monetary base arising from the above institutional changes created a serious problem for its targeted aggregate. As the 1988 year unfolded, it became clear that the Swiss National Bank had guessed wrong in predicting the effects of these shocks so that the demand for monetary base fell by more than the predicted amount, resulting in monetary policy that was too easy even though the monetary target was undershot. The result was a subsequent rise in inflation to above the $5 \%$ level.

The result of these problems with monetary targeting has resulted in a substantially loosening of the monetary targeting regime in Switzerland. The Swiss National Bank recognized that its money-growth targets were of diminished utility as a means of signaling the direction of monetary policy. As a result its announcement at the end of 1990 of the medium-term growth path of was quite ambiguous because it did not specify a horizon for the target or the starting point of the growth path. Eventually the Bank specified the time horizon of the horizon was a period of three to five years and it was not till the end of 1992 that the Bank specified the basis of the starting point for the expansion path. Finally at the end of 1994, the Bank announced a new medium-term path for money base growth for the period 1995 to 1999, thus retroactively revealing that the horizon of the first path was also five years. Clearly, the Swiss National Bank has moved to a much more flexible framework in which hitting one-year targets for money base growth has been abandoned. Nevertheless, Swiss monetary policy has continued to be successful in controlling inflation, with inflation rates falling back down below the 1\% level after the temporary bulge in inflation from 1989-1992.

There are two key lessons our discussion of German and Swiss monetary targeting. First, a targeting regime can restrain inflation in the longer run, even when the regime permits substantial 
target misses. Thus adherence to a rigid policy rule has not been found to be necessary to obtain good inflation outcomes. Second, the key reason why monetary targeting has been reasonably successful in these two countries, despite frequent target misses, is that the objectives of monetary policy are clearly stated and both the Bundesbank and the Swiss National Bank actively engage in communicating the strategy of monetary policy to the public, thereby enhancing transparency of monetary policy and accountability of the central bank.

As we will see in the next section, these key elements of a successful targeting regime -flexibility, transparency and accountability - are also important elements in inflation-targeting regimes. Thus, as suggested by Bernanke and Mishkin (1997), German and Swiss monetary policy is actually closer in practice to inflation targeting than it is to Friedman-like monetary targeting, and thus might best be thought of as "hybrid" inflation targeting.

\section{Inflation Targeting}

Given the breakdown of the relationship between monetary aggregates and goal variables such as inflation, many countries have recently adopted inflation targeting as their monetary policy regime. New Zealand was the first country to formally adopt inflation targeting in 1990, with Canada following in 1991, the United Kingdom in 1992, Sweden in 1993, Finland in 1993, Australia in 1994 and Spain in 1994. Israel and Chile have also adopted a form of inflation targeting.

Inflation targeting involves several elements: 1) public announcement of medium-term numerical targets for inflation; 2) an institutional commitment to price stability as the primary, longrun goal of monetary policy and to achievement of the inflation goal; 3) an information inclusive strategy, with a reduced role for intermediate targets such as money growth; 4) increased transparency of the monetary policy strategy through communication with the public and the markets about the plans and objectives of monetary policymakers; and 5) increased accountability of the 
central bank for attaining its inflation objectives. $^{7}$

Inflation targeting has several important advantages. In contrast to exchange-rate targeting, but like monetary targeting, inflation targeting enables monetary policy to focus on domestic considerations and to respond to shocks to the domestic economy. Inflation targeting also has the advantage that velocity shocks are largely irrelevant because the monetary policy strategy no longer relies on a stable money-inflation relationship. Indeed, an inflation target allows the monetary authorities to use all available information, and not just one variable, to determine the best settings for monetary policy.

Inflation targeting, like exchange-rate targeting, also has the key advantage that it is readily understood by the public and is thus highly transparent. Monetary targets are less likely to be easily understood by the public than inflation targets, and if the relationship between monetary aggregates and the inflation goal variable is subject to unpredictable shifts, as has occurred in many countries including a long-standing monetary targeter such as Switzerland, then monetary targets lose their transparency because they are no longer able to accurately signal the stance of monetary policy.

Because an explicit numerical inflation target increases the accountability of the central bank, inflation targeting also has the potential to reduce the likelihood that the central bank will fall into the time-inconsistency trap in which it tries to expand output and employment by pursuing overly expansionary monetary policy. But since time-inconsistency is more likely to come from political pressures on the central bank to engage in overly expansionary monetary policy, a key advantage of inflation targeting is that it can help focus the political debate on what a central bank can do in the long-run -- that is, control inflation -- rather than what it cannot do -- raise economic growth and the number of jobs permanently through expansionary monetary policy. Thus inflation targeting has the potential to reduce political pressures on the central bank to pursue inflationary monetary policy and thereby reduce the likelihood of time-inconsistent policymaking.

Despite the rhetoric about pursuing "price stability", in practice all the inflation-targeting countries have chosen to target the inflation rate rather than the level of prices per se. In addition,

${ }^{7}$ Detailed analyses of experiences with inflation targeting can be found in Goodhart and Vinals (1994), Leiderman and Svensson (1995), Haldane (1995), McCallum (1996), Mishkin and Posen (1997) and Bernanke, Laubach, Mishkin and Posen (1999). 
all the inflation targeters have chosen midpoints for their inflation target to be substantially above zero, and above reasonable estimates of possible upward measurement bias in the inflation rates calculated from consumer price indices. For example, currently New Zealand has the lowest midpoint for an inflation target, 1.5\%, while Canada and Sweden set the midpoint of their inflation target at $2 \%$; the United Kingdom, Australia and Spain currently have their midpoints at $2.5 \%$, while Israel is at $8.5 \%$. It is important to note that even Germany, considered to be one of the most resolute opponents of inflation in the world, sets its long-run inflation goal at $2 \%$ for many years (changed to 1.5 to $2 \%$ in December 1996), right in the middle of the pack for inflation targeters.

The decision by inflation targeters (and hybrid targeters like Germany) to choose inflation targets well above zero and not price level targets reflects monetary policymakers concerns that too low inflation, or particularly low inflation, can have substantial negative effects on real economic activity. ${ }^{8}$ There are particularly valid reasons for fearing deflation, including the possibility that it might promote financial instability and precipitate a severe economic contraction (see Mishkin, 1991 and 1997). Indeed, deflation has been associated with deep recessions or even depressions, as in the 1930s, and the recent deflation in Japan has been one factor that has weakened the financial system and the economy. Targeting inflation rates of above zero makes periods of deflation less likely. The evidence on inflation expectations from surveys and interest rate levels (Almeida and Goodhart, 1998, Laubach and Posen (1997) and Bernanke, Laubach, Posen and Mishkin, 1999) suggest that maintaining a target for inflation above zero (but not too far above) for an extended period does not lead to instability in inflation expectations or to a decline in the central bank's credibility.

Another key feature of inflation-targeting regimes is that they do not ignore traditional stabilization goals. Central bankers responsible in inflation-targeting countries continue to express their concern about fluctuations in output and employment, and the ability to accommodate short-run stabilization goals to some degree is built into all inflation-targeting regimes. All inflation-targeting

${ }^{8}$ For example, Akerlof, Dickens and Perry (1996) argue that inflation below 2\% can lead to higher unemployment because of downward rigidities in wages. However, as pointed out in Groshen and Schweitzer (1996), Akerlof, Dickens and Perry (1996) do not take into account forces that operate in the opposite direction, that is, that high and variable inflation rates may increase the noise in relative wages, reducing their information content and hence the efficiency of the process by which workers are allocated across occupations and industries. In other words, higher inflation can represent "sand" as well as "grease" in the labor market. 
countries have been willing to take a gradualist approach to disinflation in order to minimize output declines by lowering medium-term inflation targets towards the long-run goal slowly over time.

In addition, many inflation targeters, particularly the Bank of Canada, have emphasized that the floor of the target range should be emphasized every bit as much as the ceiling, thus helping to stabilize the real economy when there are negative aggregate demand shocks. Indeed, inflation targets can increase the flexibility of the central bank to respond to declines in aggregate spending because declines in aggregate demand that cause the inflation rate to fall below the floor of the target range will automatically stimulate the central bank to loosen monetary policy without fearing that its action will trigger a rise in inflation expectations.

Another element of flexibility in inflation-targeting regimes is that deviations from inflation targets are routinely allowed in response to supply shocks. First, the price index on which the official inflation targets are based is often defined to exclude or moderate the effects of "supply shocks;" for example, the officially targeted price index may exclude some combination of food and energy prices, indirect tax changes, terms-of-trade shocks, and the direct effects of interest rate changes on the index (for example, through imputed rental costs). Second, following (or in anticipation) of a supply shock, such as a rise in the value-added tax, the normal procedure is for the central bank first to deviate from its planned policies as needed and then to explain the reasons for its action to the public. New Zealand, on the other hand, has an explicit escape clause in its targeting regime which the central bank uses to justify such actions, although it has also permitted target deviations on a more ad hoc basis. Inflation-targeting regimes also put great stress making policy transparent -- policy that is clear, simple, and understandable -- and on regular communication with the public. The central banks have frequent communications with the government, some mandated by law and some in response to informal inquiries, and their officials take every opportunity to make public speeches on their monetary policy strategy. These channels are also commonly used in countries that have not adopted inflation targeting, Germany and the United States being prominent examples, but inflation-targeting central banks have taken public outreach a step further: not only have they engaged in extended public information campaigns, even engaging in the distribution of glossy brochures, but they have engaged in publication of Inflation Report type documents (originated by the Bank of England).

The publication of Inflation Reports is particularly noteworthy because these documents 
depart from the usual, dull-looking, formal reports of central banks to take on the best elements of textbook writing (fancy graphics, use of boxes) in order to better communicate with the public. An excellent description of the shift in emphasis in these reports is reflected in the following quote from the Bank of Canada.

The new Monetary Policy Report will be designed to bring increased transparency and accountability to monetary policy. It will measure our performance in terms of the Bank's targets for controlling inflation and will examine how current economic circumstances and monetary conditions in Canada are likely to affect future inflation. (Bank of Canada, 1995, p. 7)

The above channels of communication are used by central banks in inflation-targeting countries to explain the following to the general public, financial market participants and the politicians: 1) the goals and limitations of monetary policy, including the rationale for inflation targets; 2) the numerical values of the inflation targets and how they were determined, 3) how the inflation targets are to be achieved, given current economic conditions; and 4) reasons for any deviations from targets. These communication efforts have improved private-sector planning by reducing uncertainty about monetary policy, interest rates and inflation; they have promoted public debate of monetary policy, in part by educating the public about what a central bank can and cannot achieve; and they have helped clarify the responsibilities of the central bank and of politicians in the conduct of monetary policy.

Another key feature of inflation-targeting regimes is the tendency toward increased accountability of the central bank. Indeed, transparency and communication go hand in hand with increased accountability. The strongest case of accountability of a central bank in an inflationtargeting regime is in New Zealand, where the government has the right to dismiss the Reserve Bank's governor if the inflation targets are breached, even for one quarter. In other inflation-targeting countries, the central bank's accountability is less formalized. Nevertheless, the transparency of policy associated with inflation targeting has tended to make the central bank highly accountable to both the public and the government. Sustained success in the conduct of monetary policy as measured against 
a pre-announced and well-defined inflation target can be instrumental in building public support for a central bank's independence and for its policies. This building of public support and accountability occurs even in the absence of a rigidly defined and legalistic standard of performance evaluation and punishment.

Two remarkable examples illustrate the benefits of transparency and accountability in the inflation-targeting framework. ${ }^{9}$ The first occurred in Canada in 1996, when the president of the Canadian Economic Association made a speech criticizing the Bank of Canada for pursuing monetary policy that he claimed was too contractionary. His speech sparked off a widespread public debate. In countries not pursuing inflation targeting, such debates often degenerate into calls for the immediate expansion of monetary policy with little reference to the long-run consequences of such a policy change. In this case, however, the very existence of inflation targeting channeled the debate into a substantive discussion over what should be the appropriate target for inflation, with both the Bank and its critics obliged to make explicit their assumptions and estimates of the costs and benefits of different levels of inflation. Indeed, the debate and the Bank of Canada's record and responsiveness led to increased support for the Bank of Canada, with the result that criticism of the Bank and its conduct of monetary policy was not a major issue in the 1997 elections as it had been before the 1993 elections.

The second example occurred upon the granting of operational independence to the Bank of England on May 6, 1997. Prior to that date, it was the government, as represented by the Chancellor of the Exchequer (equivalent to the finance minister or the secretary of the treasury), that controlled the decision to set monetary policy instruments, while the Bank of England was relegated to acting as the government's counterinflationary conscience. On May 6, the new Chancellor of the Exchequer, Gordon Brown, announced that the Bank of England would henceforth have the responsibility for setting both the base interest rate and short-term exchange-rate interventions. Two factors were cited by Chancellor Brown that justify the government's decision: first was the Bank's successful performance over time as measured against an announced clear target; second was the increased accountability that an independent central bank is exposed to under an inflation-targeting

\footnotetext{
${ }^{9}$ Both are discussed more extensively in Mishkin and Posen (1997) and Bernanke, Laubach, Mishkin and Posen (1999).
} 
framework, making the Bank more responsive to political oversight. The granting of operational independence to the Bank of England occurred because it would now be operating under a monetary policy regime that ensures that monetary policy goals cannot diverge from the interests of society for extended periods of time, yet monetary policy can be insulated from short-run political considerations. An important benefit of an inflation-targeting regime is therefore that it makes it more palatable to have an independent central bank which focuses on long-run objectives, but which is consistent with a democratic society because it is accountable.

The performance of inflation-targeting regimes has been quite good. Inflation-targeting countries seem to have significantly reduced both the rate of inflation and inflation expectations beyond that which would likely have occurred in the absence of inflation targets. ${ }^{10}$ Furthermore, once inflation is down, it has stayed down; following disinflations, the inflation rate in targeting countries has not bounced back up during subsequent cyclical expansions of the economy.

Also inflation targeting seems to ameliorate the effects of inflationary shocks. For example, shortly after adopting inflation targets in February 1991, the Bank of Canada was faced with a new goods and services tax (GST) -- an indirect tax similar to a value-added tax -- an adverse supply shock that in earlier periods might have led to a ratcheting up in inflation. Instead the tax increase led to only a one-time increase in the price level; it did not generate second- and third-round rises in wages in prices that would led to a persistent rise in the inflation rate. Another example is the experience of the United Kingdom and Sweden following their departures from the ERM exchangerate pegs in 1992. In both cases, devaluation would normally have stimulated inflation because of the direct effects on higher export and import prices and the subsequent effects on wage demands and price-setting behavior. Again it seems reasonable to attribute the lack of inflationary response in these episodes to adoption of inflation targeting, which short-circuited the second- and later-round effects and helped to focus public attention on the temporary nature of the devaluation shocks. Indeed, one reason why inflation targets were adopted in both countries was to achieve exactly this

\footnotetext{
${ }^{10}$ Laubach and Posen (1997) and Bernanke, Laubach, Mishkin and Posen (1999) find that inflation expectations fell subsequent to adoption of inflation targeting and that inflation remained lower after adoption of inflation targeting than would have been forecast using VARs estimated with data from the period before inflation targeting started.
} 
result.

Although inflation targeting does appear to be successful in moderating and controlling inflation, the likely effects of inflation targeting on the real side of the economy are more ambiguous. Economic theorizing often suggests that a commitment by a central bank to reduce and control inflation should improve its credibility and thereby reduce both inflation expectations and the output losses associated with disinflation. Experience and econometric evidence (e.g., see Almeida and Goodhart, 1998, Laubach and Posen, 1997, Bernanke, Laubach, Mishkin and Posen, 1999) does not support this prediction, however. Inflation expectations do not immediately adjust downward following the adoption of inflation targeting. Furthermore, there appears to be little if any reduction in the output loss associated with disinflation, the sacrifice ratio, among countries adopting inflation targeting.

A common concern raised about inflation targeting is that it will lead to low and unstable growth in output and employment. Although inflation reduction is associated with below-normal output during disinflationary phases in inflation-targeting regimes, once low inflation levels have been achieved, output and employment return to levels at least as high as they were previously. A conservative conclusion is that, once, low inflation is achieved, inflation targeting is not harmful to the real economy. Given the strong economic growth after disinflation was achieved in many countries that have adopted inflation targets, New Zealand being one outstanding example, a case can even be made that inflation targeting promotes real economic growth in addition to controlling inflation.

Some economists, such as Friedman and Kuttner (1996), have criticized inflation targeting because they believe that it imposes a rigid rule on monetary policymakers that does not allow them enough discretion to respond to unforeseen circumstances. This criticism is one that has featured prominently in the rules-versus-discretion debate. For example, policymakers in countries that adopted monetary targeting did not foresee the breakdown of the relationship between these aggregates and goal variables such as nominal spending or inflation. With rigid adherence to a monetary rule, the breakdown in their relationship could have been disastrous. However, the interpretation of inflation targeting as a rule is incorrect and stems from a confusion that has been created by the rules-versus-discretion debate. In my view, the traditional dichotomy between rules 
and discretion can be highly misleading. Useful policy strategies exist that are "rule-like" in that they involve forward-looking behavior which constrains policymakers from systematically engaging in policies with undesirable long-run consequences, thereby avoiding the time-inconsistency problem. These policies would best be described as "constrained discretion."

Indeed, inflation targeting can be described exactly in this way. As emphasized above, inflation targeting as actually practiced is very far from a rigid rule. First, inflation targeting does not provide simple and mechanical instructions as to how the central bank should conduct monetary policy. Rather, inflation targeting requires that the central bank use all available information to determine what are the appropriate policy actions to achieve the inflation target. Unlike simple policy rules, inflation targeting never requires the central bank to ignore information and focus solely on one key variable. Second, inflation targeting as practiced contains a substantial degree of policy discretion. As we have seen, inflation targets have been modified depending on economic circumstances. Furthermore, central banks under inflation-targeting regimes have left themselves considerable scope to respond to output growth and fluctuations through several devices.

However, despite its flexibility, inflation targeting is not an exercise in policy discretion as subject to the time-inconsistency problem. The strategy of hitting an inflation target, by its very nature, forces policymakers to be forward looking rather than narrowly focused on current economic conditions. Further, through its transparency, an inflation-targeting regime increases the central bank's accountability, which constrains discretion so that the time-inconsistency problem is ameliorated.

\section{V. \\ Monetary Policy With an Implicit But not an Explicit Nominal Anchor}

Several countries in recent years, most notably the United States, have achieved excellent macroeconomic performance (including low and stable inflation) without using an explicit nominal anchor such as a target for the exchange rate, a monetary aggregate target, or inflation. Although in 
the U.S. case, no explicit strategy has been articulated, a coherent strategy for the conduct of monetary policy exists nonetheless. This strategy involves an implicit, but not an explicit nominal anchor in the form of an overriding concern by the Federal Reserve to control inflation in the long run. In addition it involves forward-looking behavior in which there is careful monitoring for signs of future inflation, coupled with periodic "preemptive strikes" by monetary policy against the threat of inflation.

As has been emphasized by Milton Friedman, monetary policy effects have long lags. In industrialized countries with a history of low inflation, the inflation process seems to have tremendous inertia: estimates from large macroeconometric models of the U.S. economy, for example, suggest that monetary policy takes over a year to affect output and over two years to have a significant impact on inflation. For other countries whose economies respond more quickly to exchange rate changes or that have experienced highly variable inflation, and therefore have more flexible prices, the lags may be shorter.

The presence of long lags means that monetary policy can not wait until inflation has already reared its ugly head before responding. If the central bank waited until overt signs of inflation appeared, it would already be too late to maintain stable prices, at least not without a severe tightening of policy: inflation expectations would already be embedded in the wage- and price-setting process, creating an inflation momentum that will be hard to halt. Indeed, inflation becomes much harder to control once it has been allowed to gather momentum because higher inflation expectations become ingrained in various types of contracts and pricing agreements.

In order to prevent inflation from getting started, monetary policy therefore needs to be forward-looking and preemptive: that is, depending on the lags from monetary policy to inflation, monetary policy needs to act well before inflationary pressures appear in the economy. For example, if it takes roughly two years for monetary policy to have a significant impact on inflation, then, even if inflation is quiescent currently and yet, with an unchanged stance of monetary policy, policymakers see inflation rising over the next two years, actions need to be taken today to tighten monetary policy to prevent the inflationary surge.

This preemptive monetary policy strategy is clearly also a feature of inflation-targeting regimes because monetary policy instruments are adjusted to take account of the long lags in their 
effects in order to hit future inflation targets. However, the policy regime in the United States, which does not have a nominal anchor and so might best be described as a "just do it" policy regime, differs from inflation targeting in that it does not officially have a nominal anchor and is much less transparent in its monetary policy strategy.

The main argument for the "just do it" strategy is, simply its demonstrated success. The Federal Reserve has been able to bring down inflation in the United States from double digit levels in 1980 to around the 3\% level by the end of 1991; since then, inflation has been stable at about that level or a bit below it. The Fed conducted a successful preemptive strike against inflation from February 1994 until early 1995, when in several steps it raised the federal funds rate for 3\% to 6\% even though inflation was not increasing during this period. The subsequent lengthy expansion has brought unemployment down below 5\%, a level not seen since the 1960s, and despite the business expansion, CPI inflation actually has even fallen to a level near $2 \%$. In addition, the overall growth rate of the U.S. has continued to remain strong. Indeed, the performance of the U.S. economy has become the envy of the industrialized world in the 1990s. Given the success of the "just do it" strategy, a natural question to ask is why countries such as the United States should consider other monetary policy strategies which would change something that has already worked well, especially given the inability to know what types of challenges will confront monetary policy in the future: In other words, "If it ain't broke, why fix it?" The answer is that the "just do it" strategy has some disadvantages that may cause it to work less well in the future.

An important disadvantage of the "just do it" strategy is a lack of transparency. The constant guessing game about the Fed's intentions created by its close-mouthed approach creates unnecessary volatility in financial markets and arouses uncertainty among producers and the general public about the future course of inflation and output as well. Furthermore, the opacity of its policymaking is hardly conducive to making the Federal Reserve accountable to Congress and the general public, because there are no predetermined criteria for judging its performance.

As a result, the central bank is more susceptible to the time-inconsistency problem, whereby it may pursue short-term objectives at the expense of long-term ones.

The lack of an explicit nominal anchor is also a potential problem for the "just do it" strategy: For example, it may be that the Fed risks greater exposure than is necessary to "inflation scares" -- 
the spontaneous increases in inflation fears described by Goodfriend (1993) that can become selfjustifying if accommodated by the Fed. In addition, this strategy may make it harder for the Fed to contain the medium-term effects of a supply shock because the absence of a nominal anchor makes inflation expectations more susceptible to rise in the face when this occurs.

Probably the most serious problem with the "just do it" approach is strong dependence on the preferences, skills, and trustworthiness of the individuals in charge of the central bank. In the United Sates, Federal Reserve Chairman Alan Greenspan and other Federal Reserve officials have emphasized forward-looking policies and inflation control, with great success so far. The Fed's prestige and credibility with the public have risen accordingly. But the Fed's leadership will eventually change, and there is no guarantee that the new team will be committed to the same approach. Nor is there any guarantee that the relatively good working relationship now existing between the Fed and the executive branches will continue. In a different economic or political environment, the Fed might face strong pressure to engage in over expansionary policies, raising the possibility that timeinconsistency may become a more serious problem. In the past, after a successful period of low inflation, the Federal Reserve has reverted to inflationary monetary policy -- the 1970s are one example -- and without an explicit nominal anchor, this could certainly happen again in the future.

The political problem with the U.S. regime in which there is no explicit nominal anchor is illustrated by events during the spring of 1997. At that time, following several previous reductions of the federal funds rate, the Federal Reserve reversed its policy and hiked the target for the funds rate by 25 basis points (one-quarter of a percentage point). Although that rise was quite modest, particularly given the strong growth of the U.S. economy and the tight labor market at the time, it provoked a storm of criticism, in Congress and elsewhere. Yet at about the same time, increases in interest rates engineered by the Bank of England, an established inflation targeter, were received quite calmly by the British public. Because of inflation targeting, it is plausible that the British public had a better understanding of the long-run objectives being pursued by the monetary authorities, and hence of the reason for their policy action, than the U.S. public. The absence of an explicit nominal anchor and the accompanying transparency, may thus make it harder for the Federal Reserve to contain inflation in the future if it undesirable shocks begin to propel inflation upward. 


\section{VI. An Overall Assessment of the Different Monetary Regimes}

In examining international experiences with different monetary policy regimes, we have looked at four basic types of frameworks: 1) exchange-rate targeting, 2) monetary targeting, 3) inflation targeting, and 4) monetary policy with an implicit but not an explicit nominal anchor. How do these different monetary policy regimes stack up against each other? When might one monetary regime be more effective in producing desirable economic outcomes than another?

Our discussion of exchange-rate targeting suggests that despite its advantages -- its ability to directly lower inflation and inflation expectations, its provision of an automatic rule and a nominal anchor that can avoid the time-inconsistency problem, and its simplicity and clarity -- this strategy can be highly problematic. The usual criticisms are that exchange-rate targeting implies a loss of independent monetary policy to respond to domestic considerations, increased transmission of shocks from the anchor, foreign country to the domestic economy, and increased likelihood of costly speculative attacks. However, for emerging market countries there are two additional major disadvantages that make exchange-rate targeting potentially dangerous: it increases the likelihood of a full-fledged financial crisis stemming from a successful speculative attack that can be devastating to the economy, and it can weaken accountability of policymakers because signals from the foreign exchange market are no longer available.

Given the above disadvantages, when might exchange-rate targeting make sense? In industrialized countries, the biggest cost to exchange-rate targeting is the loss of an independent monetary policy to deal with domestic considerations. If an independent, domestic monetary policy can be conducted responsibly, this can be a serious cost indeed, as the comparison between the experience of France and the United Kingdom indicate. However, not all industrialized countries have found that they are capable of conducting their own monetary policy successfully, either because of the lack of independence of the central bank or because political pressures on the central bank lead to an inflation bias in monetary policy. In these cases, giving up independent control of domestic monetary policy may not be a great loss when the exchange-rate is targeted, and yet the gain from an exchange-rate target of having monetary policy determined by a better performing central bank 
in the anchor country can be substantial. The case of Italy immediately comes to mind. It is not an accident that the Italian public is the most favorable of all those in Europe to european monetary union. The past record of Italian monetary policy has not been good and the Italian public recognizes that having monetary policy controlled by more responsible outsiders has benefits that far outweigh the costs of losing the ability to focus monetary policy on domestic considerations.

A second reason why industrialized countries might find it useful to target exchange rates is because it serves another purpose, such as encouraging integration of the domestic economy with its neighbors. Clearly this is the rationale for long-standing pegging of the exchange rate to the deutsche mark by countries such as Austria and the Netherlands, and the more recent exchange-rate pegs in the run-up to the European Monetary Union. The key point is that exchange-rate targeting for industrialized is probably not the best monetary policy strategy for stabilization purposes unless domestic monetary and political institutions are not conducive to good monetary policymaking or if there are other important benefits of an exchange rate target that have nothing to do with stabilization.

In the case of emerging market countries, exchange-rate targeting is highly problematic because it can promote financial fragility. As we have seen recently in Mexico and East Asia, exchange-rate targeting has been followed by disastrous financial crises which have devastated their economies. However, in countries whose political and monetary institutions are particularly weak and therefore have been experiencing continued bouts of hyperinflation, exchange-rate targeting may be the only way to break inflationary psychology and stabilize the economy. In this situation, exchange-rate targeting is the stabilization policy of last resort.

However, targeting the exchange rate with only a weak and nontransparent commitment mechanism, as most emerging market countries have done, has the potential to be disastrous. If exchange-rate targeting is believed to be the only route possible to stabilize the economy, then an emerging market country is probably best served by going all the way and adopting a currency board in which the commitment to the fixed exchange rate is extremely strong and there is total transparency to monetary policy because the actions of the central bank are automatic. However, as is discussed further in Mishkin (1998a), a currency board is still a potentially dangerous monetary policy regime which requires important institutional reforms in order to make it viable. 
The second monetary policy regime discussed here, monetary targeting, has several attractive features: in contrast to exchange-rate targeting, it allows a focus of monetary policy on domestic considerations; it provides a nominal anchor that can help avoid the time-inconsistency problem; and it can send almost immediate signals about the stance of monetary policy which can enhance accountability. Supporters of monetary targeting also point out that Germany and Switzerland have used this approach to control inflation over a substantial period of time.

The consideration of monetary targeting is not just academic since the Governing Council of the European Central Bank (ECB) announced in October, 1998, that a component of its monetary policy strategy is "a prominent role for money with a reference value for the growth of a monetary aggregate." One of the key reasons why some form of monetary targeting is an element in the ECB's announced strategy is that it European policymakers believe that it will enable the European Central Bank to inherit some of the Bundesbank's credibility. This view has been expressed by the European Monetary Institute (1997, p. 11), the precursor to the ECB: "the adoption of monetary targeting in Stage Three (of the unification process) would offer the advantage of ensuring continuity with the strategy of the EU central bank which has performed an anchor function in the ERM, in view of its long-term track record of fighting inflation. Following a monetary targeting strategy might therefore help the ESCB [European System of Central Banks] to inherit credibility from the start of its operations."

However, our earlier discussion suggests several reasons why monetary targeting, especially for the EMU may not work well. First, monetary aggregates are not a particularly useful guide for monetary policy unless the relationship between monetary aggregates and inflation is strong and reliable. A stable relationship between money and inflation is, in fact, quite unlikely to exist in the fledgling EMU, since this relationship has not been particularly reliable in the past in most of the constituent countries of the Union, including even Germany (Estrella and Mishkin, 1996). The Bundesbank has not been unaware of the instability of the money-inflation relationship, which helps to explain why it has been willing to tolerate misses of its money-growth targets in half of the years for which the targets have been set. Furthermore, the creation of the European Monetary Union and the European System of Central Banks at the start of Stage Three, together with ongoing financial deregulation and innovation, will cause major change in the operation of the European financial 
system in coming years. Those changes will affect money and asset demands in unpredictable ways, making it likely that the relationship between monetary aggregates and inflation in the Union as a whole will be even more unstable than it has been in the individual member countries.

The second objection to the adoption of monetary targeting by the European Monetary Union is that monetary targets are likely to prove a less effective vehicle of communication for the EMU than they have for Germany and Switzerland. Despite frequent target misses, both the Bundesbank and the Swiss National Bank are held in such high regard that they lose little by using the announcement of monetary targets as the framework in which they explain their policy strategy, despite the fact that their actual inflation targeting leads them to miss their stated monetary targets so frequently. The European Central Bank, which will be starting from scratch, will not at the outset command the credibility and anti-inflation reputation of the Bundesbank and the Swiss National Bank, which are based primarily on strong political support for low inflation in those two countries and on the demonstrated success of the two central banks in fighting inflation. Missing announced targets for money growth may thus be far more problematic for the European Central Bank than it was for the Bundesbank and the Swiss National Bank, because the public will be less willing to accept the European Central Bank's explanations for these misses and declarations of anti-inflationary determination at face value. Furthermore, in many European countries the public will have no experience with a monetary policy focused on monetary aggregates, and thus may find the targets harder to understand and less relevant to their daily lives than targets for inflation.

Inflation targeting, which is the newest of the monetary regimes studied here, has been gaining popularity in recent years and has several major strengths. It enables monetary policy to focus on domestic considerations as does monetary targeting, but is not subject to velocity shock problems; it is readily understood and highly transparent; it allows flexibility and discretion in the conduct of monetary policy, but because it increases the accountability of the central bank it constrains discretion so that the time-inconsistency problem is ameliorated; and it helps shift the public debate to a focus what monetary policy can do in the long run and thus helps reduce political pressure to engage in time-inconsistent policies.

Inflation targeting is not without its problems, however. In contrast to exchange-rate and monetary targeting, inflation is not easily controlled by the monetary authorities. This can be a 
particularly severe problem for an emerging market country that is trying to bring down inflation from a previously high level and so is more likely to experience large inflation forecast errors. This suggests that hard targets from inflation might be worth phasing in only after there has been some successful disinflation. This is exactly the strategy followed by Chile (see Morande and SchmidtHebbel, 1997) which adopted a weak form of inflation targeting in September 1990. Initially, inflation targets were announced and interpreted as official inflation projections, rather than as hard targets. However, over time as inflation fell, this procedure was changed and inflation targets came to be viewed by the central bank and the markets as hard targets. Waiting to harden targets until after some success has already been achieved on the inflation front, is also consistent with what inflationtargeting industrialized countries have done: in every case, inflation targeting was not implemented until after substantial disinflation has previously been achieved (see Mishkin and Posen, 1997, and Bernanke, Laubach, Mishkin and Posen, 1999).

Another potential problem with inflation targeting is that, because of the long lags of monetary policy, inflation outcomes are revealed only after a substantial lag; thus inflation targeting does not provide immediate signals to both the public and the markets about the stance of monetary policy. However, we have seen that exchange-rate targets remove the ability of the foreign exchange market to signal that overly expansionary monetary policies might be in place, while the signals provided by monetary aggregates are unlikely to be very strong because of the instability of the relationship between money and inflation.

In addition to "reference values" for monetary aggregates, the announced strategy of the European Central Bank also includes a numerically explicit inflation goal of a year-on-year increase of below $2 \%$. Because the signals from monetary aggregates are even more likely to be weak when the European Monetary Union comes into existence and a key element of any successful targeting strategy is transparency and effective communication with the public, the European Central Bank is likely to be better served by downgrading the attention to monetary aggregates and putting inflation targets at the forefront instead.

But what about the need of the European Central Bank to inherit the mantle of the Bundesbank, a monetary targeter of long standing? Doesn't this suggest that the European Central Bank should adopt monetary targeting in order to provide continuity with the policies of the 
Bundesbank, thereby inheriting the Bundesbank's credibility? There are indeed benefits for the European Central Bank to be seen as following in the footsteps of the Bundesbank. However, as the discussion here and the more detailed discussion in Mishkin and Posen (1997) and in our forthcoming book, Bernanke, Laubach, Mishkin and Posen (1999) demonstrates, the Bundesbank's policy framework is actually quite close to inflation targeting. Both frameworks have many characteristics in common, including: a strong commitment to price stability; the specification of numerical inflation goals (both in the medium term and the long term); accountability of the central bank for meeting the goals; transparency of policy and effective communication with the public; a forward-looking approach that takes into account the lags inherent in monetary policy; and flexibility to respond to short-run economic developments. In short, in practice an inflation-targeting European Central Bank would function very much like the monetary targeting Bundesbank, and the public could be actively educated to understand this basic continuity. The differences that exist -- notably, the deemphasis on money growth as the key piece of information for forecasting inflation -- favor the inflationtargeting approach.

The performance of inflation-targeting countries has been very good up to now, enabling them to maintain low inflation rates, something they have not always been able to do in the past, while it seems to improve the climate for economic growth after the initial disinflation phase is past. However, inflation targeting is no panacea: it does not seem to enable countries to eliminate inflation from their systems without cost, and anti-inflation credibility is not achieved immediately upon the adoption of an inflation target. The evidence seems to suggest that the only way for an inflationtargeting central bank to earn credibility is the hard way: they have to earn it.

Another potential criticism of inflation targeting is that too much of a focus on inflation may lead to excessive output fluctuations. For this reason, several economists have proposed that central banks should target the growth rate of nominal GDP rather than inflation (Taylor, 1985; Hall and Mankiw, 1994). Relative to inflation, nominal GDP growth has the advantage that it does put some weight on output as well as prices in the policymaking process (although, as Hall and Mankiw, 1994, pointed out, there is no reason that the one-to-one weighting of output growth and inflation implicit in a nominal GDP target has to be the socially optimal one). With a nominal GDP target, a decline in projected real output growth would automatically imply an increase in the central bank's inflation 
target, which would tend to be stabilizing because it would automatically lead to an easier monetary policy. Cecchetti (1995) has presented simulations suggesting that policies directed to stabilize nominal GDP growth should give better overall economic performance than targeting inflation would, in part because of the difficulty of forecasting and controlling inflation.

Nominal GDP targeting is close in spirit to inflation targeting and might provide a reasonable alternative. There are four reasons, however, why I believe that inflation targeting has advantages over nominal GDP targeting. First, a nominal GDP target forces the central bank or the government to announce a number for potential GDP growth. Such an announcement is highly problematic because estimates of potential GDP growth are far from precise and change over time. Announcing a specific number for potential GDP growth may thus indicate a certainty that policymakers may not have and may also cause the public to mistakenly believe that this estimate is actually a fixed target for potential GDP growth. Announcing a potential GDP growth number is likely to be political dynamite because it opens policymakers to the criticism that they are willing to settle for growth rates that the public many consider to be too low. Indeed, a nominal GDP target may lead to an accusation that the central bank or the targeting regime is anti-growth, when the opposite is true because a low inflation rate is a means to promote a healthy economy with high growth. In addition, if the estimate for potential GDP growth is too high and becomes embedded in the public mind as a target, it can lead to a positive inflation bias, as demonstrated in the model of Barro and Gordon (1983).

Second, information on prices is more timely and more frequently reported than data on nominal GDP (and could be made even more so) -- a practical consideration that offsets some of the theoretical appeal of nominal GDP as a target. Although collection of data on nominal GDP also could be improved, measurement of nominal GDP requires data on current quantities as well as current prices and this is perhaps intrinsically more difficult to accomplish in a timely manner.

Third, the concept of inflation in consumer prices is much better understood by the public than the concept of nominal GDP, which can easily be confused with real GDP. Consequently, it seems likely that communication with the public and accountability would be better served by using an inflation rather than a nominal GDP growth target. While a significant number of central banks have adopted inflation targeting, none to our knowledge has seriously considered adopting a nominal GDP target. 
Finally, as argued above, inflation targeting as it is actually practiced allows considerable flexibility for policy in the short run. Thus it is doubtful that, in practice, nominal GDP targeting would be more effective than inflation targeting in achieving short-run stabilization, and elements of monetary policy tactics based on nominal GDP targeting could easily be built into an inflationtargeting regime. Inflation targeting, therefore, has almost all the benefits of nominal GDP targeting, but does not suffer from the problems with nominal GDP targeting arising from potential confusion about what nominal GDP is or political complications because nominal GDP requires announcement of a potential GDP growth path.

The final monetary regime discussed in this paper is the "just do it" approach followed by the United States in which there is an implicit, but not an explicit nominal anchor. The key argument for this approach is that it has worked in the past and so "if it ain't broke, why fix it?. There are several answers to this question.

First, the "just do it" strategy suffers from a lack of transparency which both leads to confusion in the market place, a lack of accountability of the central bank, and a missed opportunity to focus the public and politicians on the need for a long-run orientation of monetary policy. What we have seen is that the existence of a targeting framework has more than once nudged the political debate toward a longer-run perspective, in which the benefits of price stability are recognized. The result has been less pressure on the monetary authorities to pursue ill-advised policies that provide some temporary stimulus, but at the cost of higher inflation and impaired economic performance in the long run.

Second, replacement of the "just do it" with an inflation-targeting approach would help to depersonalize U.S. monetary policy. True, monetary policy has been excellent in recent years under the tutelage of chairmen Volcker and Greenspan. Moreover, the current members of the FOMC have demonstrated that they are convinced of the value of forward-looking monetary policy that focuses on price stability. This state of affairs has not always prevailed, however, and may not always exist in the future. Monetary policymakers are quite capable of "falling off the (anti-inflationary) wagon", as the experience of the 1970s in the United States illustrates. Adoption of inflation targeting would strengthen the central bank's commitment to the long-run goal of price stability and would make the achievement of low inflation less dependent on the competence or convictions of a few individuals. 
Third, the "just do it" approach has some inconsistencies with democratic principles. Certainly there are good reasons, notably insulation from short-term political pressures, for the central bank to have some degree of independence as the Federal Reserve currently does, and the evidence does generally support central bank independence. ${ }^{11}$ Yet the practical economic arguments for central bank independence coexist uneasily with the presumption that government policies should be made democratically, rather than by an elite group (see Mishkin, 1998b). Indeed, some recent criticisms of the Federal Reserve may have been prompted by the impression that the Fed, and particularly its chairman, have become too powerful. Moving toward inflation targeting can make the U.S. institutional framework for the conduct of monetary policy more consistent with democratic principles and avoid some of the above problems. The inflation-targeting framework promotes the accountability of the central bank to elected officials, who now have some responsibility for setting the goals for monetary policy and then monitoring the economic outcomes. However, under inflation targeting, as it has generally has been practiced, the central bank has complete control over operational decisions, a requirement for it to be accountable for achieving its assigned objectives. Thus inflation targeting helps to promote operational independence of the central bank. The example of what happened in the United Kingdom in 1997 indicates how inflation targeting can reduce the tensions between central-bank independence and democratic principles and promote central-bank independence. When operational independence was granted to the Bank of England in May 1997, the Chancellor of the Exchequer made it clear that this action had been made possible by the adoption of an inflation-targeting regime, which had increased the transparency of policy and the accountability of the Bank for achieving policy objectives set by the government.

It seems likely that U.S. monetary policy performance in the future could be improved by the adoption of inflation targeting. Inflation targeting is not too far from the current policymaking philosophy at the Federal Reserve, which has stressed the importance of price stability as the overriding, long-run goal of monetary policy. Also a move to inflation targeting is consistent with

\footnotetext{
${ }^{11}$ See Alesina and Summers (1988), Cukierman (1992) and Fischer (1994) among others. However, there is some question whether causality runs from central bank independence to low inflation, or rather, whether a third factor is involved such as the general public's preferences for low inflation that create both central bank independence and low inflation (Posen, 1995).
} 
recent steps by the Fed to increase the transparency of monetary policy, such as shortening the time before the minutes of the FOMC meeting are released and the practice of announcing the FOMC's decision about whether to change the target for the federal funds rates immediately after the conclusion of the FOMC meeting. The current conditions for adoption of inflation targeting are propitious: inflation has been low and stable for over five years; the public sees that the benefit of a low inflation environment which has helped produce a balanced, long-lived economic expansion; and the success of inflation targeting regimes in other industrialized countries is becoming increasingly apparent. Moving to a more explicit nominal anchor, as with an inflation targeting regime, can help lock in the low and stable inflation rate that the United States is currently experiencing, promoting a more stable and successful monetary policy regime in the future.

\section{VII. Conclusions}

This overview of the international experiences with different monetary policy regimes suggests that transparency and accountability are crucial to constraining discretionary monetary policy so that it produces desirable long-run outcomes. Because the devil is in the details in achieving transparency and accountability, what strategy will work best in a country depends on its political, cultural and economic institutions and its past history. The discussion here of the different international experiences with monetary policy strategies will hopefully help provide guidance for policymakers in particular countries as to which monetary policy strategy is more likely to produce low inflation, a stable economic environment, and a healthy economy. 


\section{References}

Akerlof, George, William Dickens, and George Perry. 1996. "The Macroeconomics of Low Inflation." Brookings Papers on Economic Activity, no. 1: 1-59.

Alesina, Alberto, and Lawrence H. Summers. 1993. "Central Bank Independence and Macroeconomic Performance: Some Comparative Evidence." Journal of Money, Credit, and Banking 25, no. 2 (May): 151-62.

Almeida, Alvaro, and Charles A. E. Goodhart. 1998. "Does the Adoption of Inflation Targets Affect Central Bank Behaviour?” Unpublished paper, London School of Economics, January.

Bank of Canada. 1995. Monetary Policy Report.

Barro, Robert J., and David Gordon. 1983. "A Positive Theory of Monetary Policy in a Natural Rate Model." Journal of Political Economy 91, no. 4 (August): 589-610.

Bernanke, B.S. 1983. "Non-Monetary Effects of the Financial Crisis in the Propagation of the Great Depression", American Economic Review, Vol. 73, pp. 257-76.

Bernanke, Ben S. 1983.

Bernanke, Ben S., and Ilian Mihov. 1997. "What Does the Bundesbank Target?" European Economic Review 41, no. 6 (June): 1025-53.

Bernanke, Ben S., Thomas Laubach, Adam S. Posen and Frederic S. Mishkin. 1999. Inflation Targeting: Lessons from the International Experience (Princeton University Press: Princeton, N.J.)

Bernanke, Ben S., and Frederic S. Mishkin. 1992. "Central Bank Behavior and the Strategy of 
Monetary Policy: Observations from Six Industrialized Countries." In Olivier Blanchard and Stanley Fischer, eds., NBER Macroeconomics Annual, 1992, 183-238. Cambridge: MIT Press.

Bernanke, Ben S., and Frederic S. Mishkin. 1997. "Inflation Targeting: A New Framework for Monetary Policy?" Journal of Economic Perspectives 11, no. 2 (spring): 97-116.

Calomiris, Charles W. and Gorton, Gary. 1991. "The Origins of Banking Panics: Models, Facts and Bank Regulation"in Hubbard, R.G. (ed.) Financial Markets and Financial Crises. University of Chicago Press, Chicago, pp. 109-173.

Calvo, Guillermo. 1978. "On the Time Consistency of Optimal Policy in the Monetary Economy." Econometrica 46, no. 6 (November): 1411-28.

Calvo, Guillermo A., Leiderman, Leonardo and Carmen M. Reinhart, 1994. "The Capital Inflows Problem: $\quad$ Concepts and Issues," Contemporary Economic Policy 12, July: 54-66.

Cecchetti, Stephen G. 1995. “Inflation Indicators and Inflation Policy.” In Ben S. Bernanke and Julio J. Rotemberg, eds., NBER Macroeconomics Annual, 1995, 189-219. Cambridge: MIT Press.

Clarida, Richard, Jordi Galí, and Mark Gertler. 1997. "Monetary Policy Rules in Practice: Some International Evidence.” NBER Working Paper No. 6254, November.

Clarida, Richard, and Mark Gertler. 1997. "How the Bundesbank Conducts Monetary Policy." In Christina D. Romer and David H. Romer, eds., Reducing Inflation: Motivation and Strategy, 363-406. Chicago: University of Chicago Press.

Cukierman, Alex. 1992. Central Bank Strategy, Credibility, and Independence: Theory and Evidence. Cambridge: MIT Press. 
Debelle, Guy. 1997. “Discussion.” In Philip Lowe, ed., Monetary Policy and Inflation Targeting, 118-23. Sydney: Reserve Bank of Australia.

Estrella, A. and F.S. Mishkin, 1997. Is There a Role for Monetary Aggregates in the Conduct of Monetary Policy. Journal of Monetary Economics, 40:2, (October): 279-304.

European Monetary Institute. 1997. The Single Monetary Policy in Stage Three: Specification of the Operational Framework.

Fischer, Stanley. 1994. "Modern Central Banking." In Forrest Capie, Charles A. E. Goodhart, Stanley Fischer, and Norbert Schnadt, The Future of Central Banking: The Tercentenary Symposium of the Bank of England, 262-308. Cambridge: Cambridge University Press.

Folkerts-Landau, D., Schinasi, G.J., Cassard, M., Ng, V.K., Reinhart, C.M., and M.G. Spencer, 1995. "Effect of Capital Flows on the Domestic Financial Sectors in APEC Developing Countries," in M.S. Khan and C.M. Reinhart, eds. Capital Flows in the APEC Region (International Monetary Fund: Wash. D.C. 1995): 31-57

Friedman, Benjamin M. 1995. "The Rise and Fall of the Money Growth Targets as Guidelines for U.S. Monetary Policy." Paper prepared for the Bank of Japan Seventh International Conference. Preliminary draft.

Friedman, Benjamin M. and Kenneth N. Kuttner. 1993. "Another Look at the Evidence on MoneyIncome Causality." Journal of Econometrics 57: 189-203.

Friedman, Benjamin M., and Kenneth Kuttner. 1996. "A Price Target for U.S. Monetary Policy? Lessons from the Experience with Money Growth Targets." Brookings Papers on Economic Activity, no. 1: 77-125. 
Gavin, M. and R. Hausman, 1996. "The Roots of Banking Crises: the Macroeconomic Context," in R. Hausman and L. Rojas-Suarez, eds., Banking Crises in Latin America (Interamerican Development Bank and Johns Hopkins University Press: Baltimore): 27-63.

Goodfriend, Marvin. 1993. “Interest Rate Policy and the Inflation Scare Problem: 1979-1992." Federal Reserve Bank of Richmond Economic Quarterly 79, no. 1 (Winter): 1-24.

Goodhart, Charles A. E., and José Viñals. 1994. "Strategy and Tactics of Monetary Policy: Examples from Europe and the Antipodes." In Jeffrey C. Fuhrer, ed., Goals, Guidelines, and Constraints Facing Monetary Policymakers. Federal Reserve Bank of Boston Conference Series 38: 139-87.

Groshen, Erica L., and Mark E. Schweitzer. 1996. "The Effects of Inflation on Wage Adjustments in Firm-Level Data: Grease or Sand?" Federal Reserve Bank of New York Staff Reports, no. 9.

Haldane, Andrew G., ed. 1995. Targeting Inflation. London: Bank of England.

Hall, Robert E., and N. Gregory Mankiw. 1994. "Nominal Income Targeting.” In N. Gregory Mankiw, ed., Monetary Policy, 71-94. Chicago: University of Chicago Press.

Issing, Otmar. 1996. "Is Monetary Targeting in Germany Still Adequate?" In Horst Siebert, ed., Monetary Policy in an Integrated World Economy: Symposium 1995, page numbers. Tübingen: Mohr.

Kaminsky, G.L. and C.M. Reinhart, 1996. "The Twin Crises: The Causes of Banking and Balanceof-Payments Problems," Board of Governors of the Federal Reserve System, International Finance Discussion Papers No. 544 (March).

Kydland, Finn, and Edward Prescott. 1977. "Rules Rather than Discretion: The Inconsistency of Optimal Plans." Journal of Political Economy 85, no. 3 (June): 473-92. 
Leiderman, Leonardo, and Lars E. O. Svensson. 1995. Inflation Targeting. London: Centre for Economic Policy Research.

Laubach, Thomas and Adam S. Posen. 1997. "Some Comparative Evidence on the Effectiveness of Inflation Targeting," Federal Reserve Bank of New York Working Paper \#97-14 (May).

McCallum, Bennett T. 1995. "Two Fallacies Concerning Central-Bank Independence." American Economic Review 85, no. 2 (May): 207-11.

McCallum, Bennett T. 1996. "Inflation Targeting in Canada, New Zealand, Sweden, the United Kingdom, and in General." NBER Working Paper No. 5579, May.

Mishkin, Frederic S. 1991. “Asymmetric Information and Financial Crises: A Historical Perspective.” In Glenn R. Hubbard, ed., Financial Markets and Financial Crises, 69-108. Chicago: University of Chicago Press.

Mishkin, Frederic S. 1996. "Understanding Financial Crises: A Developing Country Perspective," in Michael Bruno and Boris Pleskovic, eds., Annual World Bank Conference on Development Economics 1996 (World Bank: Washington D.C. 1996): 29-62.

Mishkin, Frederic S. 1997. "The Causes and Propagation of Financial Instability: Lessons for Policymakers." In Maintaining Financial Stability in a Global Economy, 55-96. Kansas City: Federal Reserve Bank of Kansas City.

Mishkin, Frederic S. 1998a. "Exchange-Rate Pegging in Emerging-Market Countries? International Finance, forthcoming. 
Mishkin, Frederic S. 1998b. "The Role of a Central Bank in a Democratic Society," paper prepared for the Fourth Dubrovnik Conference on Transition Economies, June 24-26, 1998.

Mishkin, Frederic S. and Adam Posen. 1997. "Inflation Targeting: Lessons from Four Countries," Federal Reserve Bank of New York, Economic Policy Review, 3 (August): 9-110.

Morande, Felipe, and Klaus Schmidt-Hebbel. 1997. "Inflation Targets and Indexation in Chile." Unpublished paper, Central Bank of Chile, August.

Neumann, Manfred. 1996. "Monetary Targeting in Germany." Paper prepared for the Bank of Japan Seventh International Conference.

Neumann, Manfred J.M., and Jurgen von Hagen. 1993. "Germany." In M. Fratianni and D. Salvatore, eds., Handbook of Monetary Policy in Industrialized Countries. Westport, Conn.: Greenwood.

Obstfeld, Maurice, and Kenneth Rogoff. 1995. "The Mirage of Fixed Exchange Rates." Journal of Economic Perspectives 9, no. 4 (fall): 73-96.

Posen, Adam S. 1995. "Declarations Are Not Enough: Financial Sector Sources of Central Bank Independence." In Ben S. Bernanke and Julio J. Rotemberg, eds., NBER Macroeconomics Annual, 1995, 253-74. Cambridge: MIT Press.

Rich, Georg. 1997. "Monetary Targets as a Policy Rule: Lessons from the Swiss Experience." Journal of Monetary Economics 39, no. 1 (June): 113-41.

Stock, James H. and Mark W. Watson. 1989. "Interpreting the Evidence on Money-Income Causality." Journal of Econometrics 40: 161-182.

Taylor, John B. 1985. "What Would Nominal GNP Targeting Do to the Business Cycle?" Carnegie- 
Rochester Conference Series on Public Policy 22: 61-84.

von Hagen, Jürgen. 1995. "Inflation and Monetary Targeting in Germany." In Leonardo Leiderman and Lars E. O. Svensson, eds., Inflation Targets, 107-21. London: Centre for Economic Policy Research. 